\title{
Class or Mass: Sport (for All) Politics at a Crossroads
}

\author{
Gyöngyi Szabó Földesi
}

Semmelweis University, Budapest, Hungary

ABSTRACT

Hungarian sport politics has long tradition not to accomplish the otherwise ideal - objectives declared in the overall sport conception for the same period. The purpose of this paper is to analyse the contemporary National Sports Strategies, the contradictory character of their realization and some major conditions of the improvement of all Hungarians' involvement in sport. By way of introduction the notions of sport policy, sport politics and sport for all politics are clarified. Then the methods for collecting information (analysis of documents, in-depth interviews and participant observation) are presented. The main body of the contribution consists of three parts. Firstly a brief overview is given on the legacy on the grounds of which the current sport politics had to start from, with great emphasis of the changing role of the state, civil society and the business sector in the process of planning, developing and supporting the population's sporting activity. Secondly the today's sport policy and the true situation in sport for all are discussed according to the following dimensions: (1) the underprivileged position of sport for all; (2) the lack of the necessary co-operation between sport and other sub-systems, such as education, public health; (3) the low proportion of state aid to be given for sport; (4) the disparity of state financing between the individual fields of sport: (5) the reinforcement of the increasing social inequality in sport. Thirdly the author makes attempts to outline a developmental trend state responsibility in sport for all by answering a crucial question: Whose responsibility is it? In conclusion it is stated that historical opportunity for changing radically the traditional sport politics was missed during the last 15-20 years. The political approach to sport by the individual governments might have been different, but the very essence of their sport politics was rather similar. The core values guiding their sport politics were very positive all the time; however they have not been realized in either period. The author is of the opinion that the vision of a "sporting nation" suggested by the present-day National Sport Strategy seems to be attractive, but she calls the attention to the missing political and financial garantees that would enable to approaching it and urges to promote a more democratic, a $\mathrm{m}$ ore just and a truly modern turn in sport politics

KEYWORDS social inequality, national sport strategy, core values, state responsibility

\section{Introduction}

Both scientific evidence and everyday experience prove that since the 1989-1990 political and economic system changes social inequalities have been increasing in the countries of the former 
Eastern Bloc, including Hungary. The social composition of Hungarian society has also been restructured and the new social classes and strata have quite different access to sport. Members of the narrow upper and upper-middle classes enjoy all means of sporting involvement. The enormous economic, cultural, and social capital in their property allows them to choose freely where, when and what sport to practise. At the other end of the social ladder the broad masses of the lower and lowermiddle classes are deprived of genuine opportunities. They simply cannot afford to spend money on sport. Therefore, under the altered circumstances in sport, their chances are strongly limited in this area of social life (as well).

Sport as a social sub-system does not contribute to diminishing social inequality; on the contrary, it reinforces such social sub-systems. In other words, in today's Hungarian society individuals' social class affiliation determines their chances of practising sport. On the one hand, the new elite can employ personal coaches and finance their children's most extravagant participation in sport, but on the other hand, the majority of the population is in an unfavorable position from this perspective.

\section{Objectives}

Following the political and economic system changes, in the early 1990s new conceptions for sport were issued. Later, since 2004, several versions of a National Sport Strategy have been prepared. The major purpose of this paper is to study the nature of these sport conceptions and the efficiency of their implementation. The author makes an attempt to give answers to the following questions:

- Have the new sport policies been adapted to the altered social and economic circumstances?

- Have the recent sport policies been accomplished by sport politics?

- Have real efforts been made to decrease the gap between "the haves" and the "have-nots" in sport? Has all Hungarians' access to sport and exercise been truly promoted?

- How can the population's involvement in sport be improved?

\section{Methods}

Information for the analysis of the above mentioned questions was collected by the following methods:

- Relevant documents (sport conceptions, sport strategies, annual reports, and minutes of parliamentary debates) were analysed.

- In-depth interviews were conducted with key actors in sport (for all) $(\mathrm{N}=23)$.

- The author has been in a position to be a participant observer, because since the second half of the 1980s she has served in national sports federations, and since the early 2000s she has been working in a national "sport for all" confederation as president, with the right and duty to make decisions. Moreover, she has been a member on the advisory committees of the highest decision-making bodies in sport.

\section{Defining Major Terms}

Since the key terms of this paper (sport policy, sport politics, "sport for all") have several meanings, it is necessary to clarify in which sense they are used here. It is relatively easy to define the 
second parts of these notions, that is policy and politics. According to the Penguin Word Master Dictionary, policy is "... a plan or a course of action adopted, esp. by a political party or business firm" (1987, p. 532); while politics is "1. the science or art of a government. 2. political affairs or activities. 3. activity concerned with gaining one's own end, esp. acquiring power in company politics. 4. one's political sympathies" (1987, p. 533). Similarly to these, according to the Oxford Advanced Learner's Dictionary of Current English, policy is a "plan of action, statement of aims and ideals, esp. one made by a government, political party, business company, ect." (1974, p. 644), and politics is "the science or art of a government; political views, affairs, questions" (1974, p. 645).

To put the above sophisticated definitions in a simpler way, for our purposes policy means statements, ideals, strategies and plans, while politics denotes their accomplishment.

It is not too difficult to explain the first part of the compounds sport policy and sport politics either. It is logical that in this context sport can refer only to a social institution, to one of the subsystems of society. What is really hard to cope with is the interpretation of the polysemous concept of "sport for all." Of course, the author does not undertake the task of resolving the decades-long terminological debates. She merely offers a potential explanation for the meaning of this term in this paper.

As a first step, it can be stated what "sport for all" does not comprise. Professional sport, top sport, elite sport, high level performance sport are definitely not included in it (Palm, 1991). As a second step, it has to be emphasized that "sport for al" does not amount to the informal sector of sport. It must not be narrowed down - as often happens in Hungary - to non-institutionalized, non-organized sporting activities and/or home based exercise practised individually or in informal groups. The latter can be considered as an important area of "sport for all". However, in our understanding, institutionalized and organized competitive sports practised in a truly amateur way constitute the other significant field of it.

Finally, the relationship between the concepts of mass sport, leisure sport, sport recreation and "sport for all" should be ascertained. There are slight differences between these terms, the evaluation of which depends partly on the historical context they are used in, and partly on the perspectives from which they are analysed (the number of participants, the purpose or the time frame of sport, etc.). Although, strictly speaking, they are not synonymous, they are frequently used as if they were, not only in everyday language but also in official documents. In Hungary the term mass sport often has a pejorative sense, since in the 1950s it was discredited. Instead of it, since the late 1960s the notion of leisure sport has been largely accepted. Since the 1990s, there have been attempts to find a good Hungarian translation for the worldwide popular expression of "sport for all". These efforts were crowed by success not long ago, and a new term, (called "mindenki sportja") has recently been introduced.

Based on national experiences and international literature, in this paper "sport for all" is regarded as "an umbrella term for recreation, sport development, mass participation programs and cultural recreation activities aiming to provide leisure opportunities and health promotion to their adherents" (DaCosta 2002. p. 15.).

\section{Legacy}

When the legacy for the basis of present-day sport policy and sport politics is discussed, in many cases only the heritage from state socialism is taken into consideration. This historical period has still a significant impact on today's events, indeed, especially as far as people's way of thinking is 
concerned. However, one and a half decades after the political system change, the nature of the socalled socialist sport model cannot be blamed completely on the lack of a truly modern turn in sport. In this paper the legacy left behind by both periods, that is by state socialism and the transformational period, is examined.

To establish the conditions for top sport was the first priority in Hungarian sport politics during the four decades of "socialism". Equal chances for other areas of sport were not guaranteed at all (Földesi, 1991). As it is stated in a recent study, "the "weakest link" in the institutional legacy of today's Hungarian sport is indisputably related to the population's sporting activity. In principle, the development of mass sport/leisure sport was regarded on an equal basis with the promotion of elite sport. In reality, it was always overshadowed and pushed into an underprivileged position, although, under certain political circumstances, true efforts were made to upgrade it" (Földesi 2005, p. 42).

In the initial part of the transformation of sport following the 1989-1990 political and economic system changes, the dominant role of the state was cut, and civil society was rediscovered and reborn. The commercial sector started developing, but the contribution of the business sector to sport did not increase considerably.

Sport policy and sport politics again came into conflict and the contradictions became even sharper in the post-transformational period. The political approach to sport by the individual governments was different with regard to their ideological reasoning, political culture and style, but the very essence of their sport policies was rather similar. In their sport conceptions the guiding principles comprised more or less the same positive core values: unity of sport, equality, promotion of excellence, health, and quality of life with the help of sport, etc. In the spirit of all these, "sport for all" was given priority in all governmental documents. In spite of encouraging declarations, "sport for all" was again pushed into an underprivileged position, sport policies were not accomplished in any period. All governments in power from 1990 until today missed the historical opportunity to radically change the traditional sport political trends; all of them supported elite sport to a much greater extent. From time to time there were some initiations to support leisure sport. For instance, a National Confederation for Hungarian Leisure Sport Federations was established in 2002 (CXLV. Act of 2002 on Sport), and state financial support was guaranteed for the functioning of national leisure sport associations. In addition, sport for people with disabilities was truly promoted. Nevertheless, on the whole, "sport for all" did not really benefit from the collapse of the socialist sport model, it was a loser again. For instance the state support for this field from 2003 to 2007 was reduced dramatically, from $1762078880 \mathrm{HUF}$, to $587100000 \mathrm{HUF}$. Of the share of the 2007 central state budget dedicated to sport, $0.96 \%$ was given for leisure sport.

There are many causes behind this unacceptable phenomenon. It is the author's conviction that one of the major reasons that sport for all Hungarians could not really develop in the last 15 years is that the decision-makers did not pay due attention to the consequences of the increasing social gaps in the population's sport.

Social class affiliation influenced individuals' sport involvement in state socialism as well; those with higher incomes and a higher level of education had a greater chance of practiscing sport also at that time (Földesi 1991, Gáldi 2002, 2004). Notwithstanding this, in the new political system the sporting habits according to social strata differ even more, since the rapidly growing socioeconomic differences, observable at a macro-level in society since 1990, have been reinforced in sport. This probably was not an unavoidable consequence of the political and economic transformation. In some other countries of the former Eastern Bloc there are not such huge social gaps in "sport for all" (Wolanska et al). 
Hungarian upper-class people's sport participation can be described by similar characteristics as for those people belonging to the elite in many other countries, including several welfare states. For instance, the three concepts by means of which Bryant and McElroy explain why in the USA individuals with high incomes, a high level of education, and high occupational status participate in certain sporting activities are relevant also for the most privileged social class in Hungary (Bryant and McElroy 1997). That is, the concepts of social exclusivity, conspicuous consumption, and control over time offer good reasons for their sporting behavior.

Conversely, when attempts were made to adopt the concepts used by the same authors to understand how the other main social groups participate in sport, it turned out that they are not relevant. According to Bryant and McElroy, middle-class physical activity can be understood by the concepts of community sponsorship, structured leisure, and home-based physical activity; workingclass physical activity can be explained through the concepts of rejection of workplace fitness and "prole" sports, while lower-class physical activity can be characterized by low participation rates and pseudo sports. These explanations are not adequate for Hungarian society because it is far more polarized, the middle class is much narrower, and the lower part of it is already hit by poverty. The lower strata of the large working class and the similarly large lower class can be classified below the poverty line.

According to statistical and even some research data, in the early 2000 s "only" $12 \%$ of the population could be considered as poor, but even these data reveal that the index expressing the chances of upward mobility, called "relative median poverty gap", has been continuously increasing: from 1992 to 2005 it climbed from 15\% to 22\% (Gábos and Szívós 2006). In addition, the 12\% figure refers to the total population, but the rate of children living under impoverished conditions is $19 \%$. Other official documents - such as the National Strategy entitled "Should Be Better for the Children" - suggest that $28 \%$ of the Hungarian population, within this $40 \%$ of the children, were living under the poverty line in 2004 (Legyen jobb a gyermekeknek 2007). Under these circumstances the state/local governments must not leave the people with low income (or without regular income) and low education to their own devices in sport. Despite this rightful claim, community-sponsored sporting opportunities are lacking or strictly limited; the workplace sport programs existing in state socialism are discontinued. The upper portion of the middle class still makes attempts at home-based fitness, but they have full-time jobs, with long hours of working time, which prevents even them from practising regularly.

Working-class people have time conflicts even more frequently, since the majority of them also work in their free time, legally or illegally. The lack of time and opportunity, as well as their deficient knowledge of a healthy lifestyle result in their low active participation. They are attracted mostly to sport consumption, generally in front of the television. "Sport for all" programs are seldom offered to them, both in their community and in their workplace.

Lower-class people are not fully regarded as a target group in sport, either in their community or in their workplace, if they have jobs at all. Their access to sporting activity, with the exception of a few goodwill or charity programs, such as for example midnight table tennis, is even smaller. Although physical strength and bodily performance are highly ranked in their sub-culture, they are rather associated with violence and aggression than actual sport. They are usually not athletes but spectators escaping from their extreme poverty, but even in this capacity they belong to the dark side of sport, constituting the masses of deviant fans, football hooligans in the first place.

Unequal access to sport can be observed in most countries, even in prosperous democratic states. However, in those countries the proportion of people living in hopeless poverty and the degree of social inequality between the different social strata are much lower than in present-day Hungary. 
According to the so-called "two-thirds society" theory, in Western European countries one-third of the population is close to poverty or already poor, while two-thirds live in prosperity and can access the attainable social, cultural (and sporting) goods. In Hungarian sport the opposite tendency can be observed. It is believed that one-third of the population can afford to engage regularly in sport, but that the situation of the remaining two-thirds can best be described as social exclusion. The otherwise narrow middle class has been shrinking, and increasing impoverishment can be observed in the lower strata of it, and also in the working and the lower classes. The polarization of Hungarian society has accelerated. Access to sport is so atrocious that it cries for institutionalized, organized public help.

\section{Sport politics without well-founded ideals}

In the last 15 years sport politics was either not constructed at all on a thorough analysis of sport as a social sub-system, or research results were adapted selectively and/or simply neglected when the ideals should have been realized.

In the first years following the 1990 political system change, only the principles in the spirit of which the new sport leadership wished to work were declared (Gallov 1992), but a theoretical approach was not developed. In 1993 a "Guideline for the Renewal of Physical Education and Sport" was published. The sport scientific, educational, and media elites - in other words the "knowledge elites" in sport - were not involved in its preparation, so no wonder it lacked any theoretical background. In these documents some major problems of Hungarian sport were summarized, but only a few proposals were made for their solutions, and it was not clarified who should be responsible for their resolution.

The lack of relevant surveys and scientifically well-founded strategies are exactly the reason that sport politics of the 1990s is characterized by Bakonyi as "seeking ways and means". In his comprehensive study on the role of the state and civil society in sport he emphasizes that the first three parliaments and the first three governments had no theoretically-based strategy on sport, therefore the direction of sport politics could be dictated by wider policies (Bakonyi 2004, 2007). Nor was the first law on sport, issued in 1996 (Act LXIV of 1996 on Sport), founded scientifically. Consequently, it can be regarded only as a framework law which could not serve as a good background to initiate the necessary reforms in sport, and amendments to it soon had to be adapted.

The second law on sport (Act CXLV of 2000 on Sport) was also issued with the primary aim of serving political purposes, and amendments to it also had to be incoporated. It was not founded on a well-prepared sport strategy; however, a clear political strategy, namely re-centralization and the reinforcement of the power of the state, could be noticed behind it. Notwithstanding this, in that period the upgrading of the National Sport Office to a ministerial rank was welcomed by most stakeholders of sport, regardless of political affiliation. The world of sport, similarly to wider society, started to be divided into two a little later on.

Only in the early 2000s did the decision-makers call on the experts for a comprehensive analysis of Hungarian sport in order to establish their sport policy. In 2002 a book, entitled "Fehér könyv" (White Book), was published Frenkl-Gallov. According to Bakonyi, although this work has indisputable professional value, its approach to the state's responsibility and to the desirable decisionmaking process seems to be reminiscent of the old days of "real existing socialism" (Bakonyi 2004, 2007). In our view, the real problem is not the standpoint portrayed by the book, which is the product of a mixed, scientific and pragmatic approach, but the fact that even its progressive messages were not taken into consideration when a newer law on sport was issued in 2004 (Act I of 2004. on Sport), again primarily for political reasons. 
Over-politicization could gain ground in Hungarian sport because neither civil society, nor the market could counterbalance the over-dominance of the state. However, there could not have been such a wide possibility for political battles and rivalries in sport, if there had been medium-term and long-term national plans for sport ensuring continuity after a change of government. In want of the latter, tremendous energy and time were consumed on internal political struggles and organizational restructuring in sport. In the meantime, sport politics has not been able to treat the consequences of the major negative transformational outcomes effectively, among other things it could not cope with the increasing social inequalities in, and social exclusion from sport.

\section{Vision of a sporting nation}

After those three laws on sport were issued based on political considerations, the need for a national sport plan became so urgent that its preparation could not be postponed any longer. The process started as early as 2003, and then several drafts of a National Sport Strategy were published. The major intention was to produce a professionally well-founded sport strategy. In contrast to this purpose, the process was stopped and then restarted every time there were personnel changes in the highest sport management and/or the highest sport authority's organization was restructured. Unfortunately, such occasions have occurred three times in the last three years. On the other hand, the ever newer versions of the National Sport Strategy were opened to public debate in a democratic way, and the main partners of the Ministry/National Office for Sport (Ministry of Education, Ministry of Public Health, the four, laterfive so-called "unregistered prominent non-profit public bodies in sport") had not only the right but also the duty to express their views on them. Their remarks and opinions were mainly taken into consideration if they were in line with the political intentions of the group that compiled the given draft.

Since they are no longer valid, there is no point in studying the individual drafts of the Strategy in detail. However, it is worth mentioning that at the beginning of the process the fundamental message suggested by sport policy altered considerably. In the first version the priority of elite sports, especially of Olympic sports, was not disguised. This was transformed soon, in the plan published at the end of 2004, and a different vision, in which the unity of a sport nation and a sporting nation was underlined, was drafted. When in 2005 it was passed as a motion to the government under the title "Sport XXI. National Sport Strategy" it had the following subtitle: "Be Hungary a Sport Nation and a Sporting Nation". Quite interestingly, the proposal was declared non-public for 20 years. It was not accepted for a long while, because although it had many good ideas the financial guarantees were not added to it. This was also the main reason that one of the national umbrella organizations, the National Confederation for Hungarian Sport for All Associations, which represented the interests of the whole population's sporting activity, did not agree with the proposal. It was the only partner which, expressing its disagreement, did not sign the document. That version of the Strategy was accepted in November 2005 by the Government in office, but it has not been yet submitted to parliament. Instead, a newer version was prepared.

In early 2007 a newer version of the Sport XXI. National Sport Strategy was published. It no longer bears the above-mentioned subtitle, but it was redrafted in a similar spirit, that is with the aim of developing both sport for all Hungarians and the national top-level sport. As a whole, it is a thoroughly elaborate piece of work, and it seems to be better than the previous versions. However, beside its positive features, it has negative ones as well. The sunny side is that "sport for all" receives much more attention in the ideals, and research evidence is used, although in an eclectic and selective way. Notwithstanding this, in its dark side it again puts at risk the chances of the common people's sport, especially the underprivileged social group's sporting activity, receiving deserved support, 
because the action plan is not in harmony with the statements. There are severe contradictions in the text which are closely connected to "sport for all". For instance, in the first chapter where the shift of paradigm is worded, diminishing social inequalities by means of sport is a declared objective (Chapter, 1/5). However, when the objectives are specified, under the title "Equality of chances", the promotion of young talents' care and regional equality are listed, but social exclusion is not dealt with (Chapter, VIII/I/8.).

Another example is that, after admitting that only $9 \%$ of the population practise sport regularly (Chapter VII/2) and that sporting and facilities are often not available (Chapter II/2/I), the development of the demand is regarded as a prominent task, without underlying the necessity to promote the supply-side (Chapter, IV/2). This approach is totally unacceptable because it neglects the large masses of the "have-nots". This is a very serious deficiency of the present Strategy which must be improved by all means.

The present draft of the National Sport Strategy pays too much attention again to the restructuring of the system of sport organizations. The attitudes behind these views might lead to surrogate actions with dysfunctional consequences. The prominent umbrella organizations established in 2001 served good aims. To put an end to their existence surely will not solve the grave problems of Hungarian sport. Nevertheless, whether there is one or five such umbrella organizations is not a question of primary importance. The main thing is that all areas of sport should have a similar ability and possibility to enforce their interest. No doubt, "sport for all" always was at a disadvantage in spite of having a separate umbrella organization. The frequently replaced senior management in sport was not able to co-ordinate between the different interest groups, and the social capital of the elite sport lobby could not be counterbalanced even by the most telling arguments.

With regard to this issue, it has to be noted that the National Sport Strategy appears to have positive prejudices in favor of top-level sport. It quotes several favorable social roles of top-level sport without referring to the negative and/or ambivalent ones that gained ground when elite sport became an industry. Moreover, the Strategy refers falsely to the Hungarian population's high level of knowledge about and positive attitudes towards elite sport based on estimation rather than scientific investigation, and it evaluates the contribution of international sport successes to national identity without recognizing the impact of globalization on it (Salga 2007).

In spite of above problems which definitely should be solved, the vision drafted by the Nation al Sport Strategy seems to be attractive. Unfortunately, it has a severe deficiency: the appropriate political and financial guarantees are again missing from it. Based on the unfavorable experiences gained over decades, the absence of these guarantees means the chance for the realization of its ideas can rightly be questioned.

\section{Conclusion}

Hungarian sport politics has a long tradition of failing to accomplish its own - otherwise ideal - objectives declared for the same period. During the four decades of state socialism the purposes of sport politics were formulated in the sole existing political party's resolutions, based on quite proper core values, but only occasionally. The plans concerning top-level sport were always over-fulfilled, but the aims relating to mass sport/leisure sport remained empty slogans.

In the initial period of the 1989-1990 political system change the dominance of political parties came to an end and desirable sport political goals were expressed, again incidentally, in state documents. However, the gap between the declared words and realized actions did not diminish 
considerably at that time, either. In manifestations the population's sporting activity was given preference, while in practice elite sport always had a great advantage over it.

In the post-transformational period the need for a comprehensive sport policy was recognized, but the elaboration of a National Sport Strategy started only as late as 2003. The process of its preparation took far longer than was intended, because at each stage of personnelal and structural changes in the highest sport authority, that is three times, it was stopped and restarted. The principle, in the spirit of which the present-day version of the National Sport Strategy has been redrafted, is basically proper. Notwithstanding this, it does have some major deficiencies. Firstly, it is not supplemented by financial guarantees and, for want of the latter, in spite of all goodwill it might remain a dream and there may be no changes. Secondly, the action plan for promoting sport for all Hungarians, eliminating social exclusion in sport and for diminishing huge social inequalities is rather poor and not really adequate.

Until today the traditional, one-sided sport policy inherited from state socialism has not been radically changed. The historical opportunity for its transformation was missed a few times. Sport policy is at a crossroads again. Either the old way will be continued in the usual hypocritical manner with half-measure arrangements or, as is strongly hoped, there will at long last be radical change, and the gap between the slogans and actions will lessen. On the one hand, support would be given to elite sport, but its dark side would be admitted, and international sport successes would not be forced at any price. On the other hand, the population's sporting activity would take genuine priority both from the political and economic perspective, not only in slogans but also in actions. The present National Sport Strategy does not give sufficient impulse and "ammunition" for that. For its improvement it is recommended that greater emphasis be given to the following issues:

To decrease the disparity between the individual fields of sport.

To promote solidarity between the different areas of sport.

To improve the co-operation between sport and other social sub-systems.

To offer community-sponsored sport programs.

To support sport organizations offering sport programs for underprivileged social groups.

To urge the media to report far more on the population's sporting activity.

Finally, the senior management of sport should mobilize all interest groups to convince the members of the Parliament that the proportion of state aid given to sport should be significantly higher, similar to most member states of the European Union.

\section{REFERENCES}

Bakonyi, T. (2005). Civil álom és politikus állam. Adalékok a civil sportszervezetek legújabb-kori politikatörténetéhez Magyarországon. PhD. Értekezés. Buapest: Semmelweis Egyetem.

Bryant, J. E., McElroy, M. (1997). Sociological Dynamic of Sport and Exercise. Morton Publishing Company. Colorado: Engelwood.

DaCosta, L., Miragaya, A. (2002). Search of Experiences and Trends of Sport for All Worldwild. In DaCosta, L. - Miragaya, A, Worldwid Experiences and Trends in Sport for All. Meyer und Meyer Verlag, Aachen. 15-31.

Frenkl, R., Gallov, R. (2002). Fehér könyv. Kézirat.

Földesi, Gy. Sz. (1991). A sportolásra fordított idő Franciaországban és Magyarországon. A Testnevelési Egyetem Közleményei , 2. (melléklet) pp. 1-111. 
Földesi Gy.Sz. (2005). Transformation of Sport in Changing Political and Economic Systems: The Hungarian Case between 1985-2000. Academic Doctoral Thesis. Buapest: Hungarian Academy of Sciences.

Gallov, R. (1992). Mennyire fontos hazánkban a sport. Nemzeti Sport. September 6-9, pp. 11-14.

Gábos, A., Szívós, P. (2006). A gyermekszegénység és néhány jellemzője Magyarországon. In Kolosi T. et al: Társadalmi riport. Budapest: TÁRKI, pp. 204-228.

Gáldi, G. (2004). Szabadidőstruktúra és fizikai reakció Magyarországon 1968-2000 között életmód-időmérleg vizsgálatok tükrében. PhD értekezés. Semmelweis Egyetem Testnevelési és Sporttudományi Kar, Budapest.

Gáldi, G. (2002). Fizikai aktivitás Magyarországon az ezredfordulón. Magyar Sporttudományi Szemle, pp. 3-4, 16-18.

Hornby, A. S. (Ed.) (1983). Oxford Advanced Learner's Dictionary of Current English. Oxford: Oxford University Press.

Manser, M. H., Turton, N. D. (Eds.) (1987). The Penguin Wordmaster Dictionary. Harmondtsworth, Middlesex, England: Penguin Books Ltd.

„Legyen jobb a gyerekeknek” (2007). Budapest: Nemzeti Stratégia.

Nemzeti Stratégia Legyen Magyarország sportnemzet és sportoló nemzet. (2005). Előterjesztés a Kormány részére. Budapest: Nemzeti Sporthivatal.

Palm, J. (1991). Sport for All: Approaches From Utopia to Reality. Schondford: Verlag Karlf Hofman.

Salga, P. (2007). A szabadidősport helyzete napjainkban. Közgazdaságtudományi Egyetem, Sportmarketing szakirány. Előadás. Kézirat. Március.

Sport XXI. Nemzeti Stratégia 2007-2020. (2007). Budapest: ÖTM, Sport Szakállamtitkárság.

Wolanska, T. et al (2002). Sport for All and Physical Culture as Social Value. In DaCosta, L., Miragaya, A. (Eds.) Worldwid Experiences and Trends in Sport for All. Aachen: Meyer und Meyer Verlag, pp. 261-290. 